\title{
REVERSED PHASE HPLC DETERMINATION OF TAMOXIFEN IN DOG PLASMA AND ITS PHARMACO- KINETICS AFTER A SINGLE ORAL DOSE ADMINISTRATION
}

Davi Pereira de Santana*, Rossana Maria Carvalho Braga, Ruth Strattmman, Miracy Muniz Albuquerque, Danilo César Galindo Bedor and Leila Bastos Leal

Departamento de Ciências Farmacêuticas, Universidade Federal de Pernambuco, Rua Prof. Arthur de Sá, s/n, 50739-520 Recife - PE, Brazil

José Alexsandro da Silva

Departamento de Farmácia, Universidade Estadual da Paraíba, Rua Juvêncio Arruda, s/n, 58109-790, Campina Grande - PB, Brazil

Recebido em 30/10/06; aceito em 25/5/07; publicado na web em 3/12/07

\begin{abstract}
The analytical method developed to evaluate tamoxifen in dog plasma samples was precise, accurate, robust and linear in the range of $5-200 \mathrm{ng} / \mathrm{mL}$. The limits of detection and quantification were $0.981 \mathrm{ng} / \mathrm{mL}$ and $2.97 \mathrm{ng} / \mathrm{mL}$, respectively. Besides, the intra-day precision and accuracy variations were 8.78 and $10.16 \%$, respectively. Tamoxifen concentrations were analyzed by combined reversed phase liquid chromatography and UV detection $(\lambda=280 \mathrm{~nm})$. The study was conducted using an open randomized 2-period crossover balanced design with a 1-week washout period between the doses. This simple, rapid and selective method is suitable for pharmacokinetic, bioavailability and bioequivalence studies.
\end{abstract}

Keywords: bioavailability; Tamoxifen; HPLC.

\section{INTRODUCTION}

Tamoxifen (CAS: 54965-24-1), chemically designated as (Z)1-[p-Dimethylaminoethoxyphenyl)-1, 2-diphenyl-1-butene, is a nonsteroidal agent that has demonstrated potent antiestrogenic properties in animal test systems. The antiestrogenic effects may be related to its ability to compete with estrogen for binding sites in target tissues such as breast. Tamoxifen citrate (Figure 1) has a molecular weight of 563.64, the $\mathrm{pKa}$ is 8.85 , the equilibrium solubility in water at $37{ }^{\circ} \mathrm{C}$ is $0.5 \mathrm{mg} / \mathrm{mL}$ and in $0.02 \mathrm{M} \mathrm{HCl}$ at $37^{\circ} \mathrm{C}$, it is $0.2 \mathrm{mg} / \mathrm{mL}^{1-4}$.

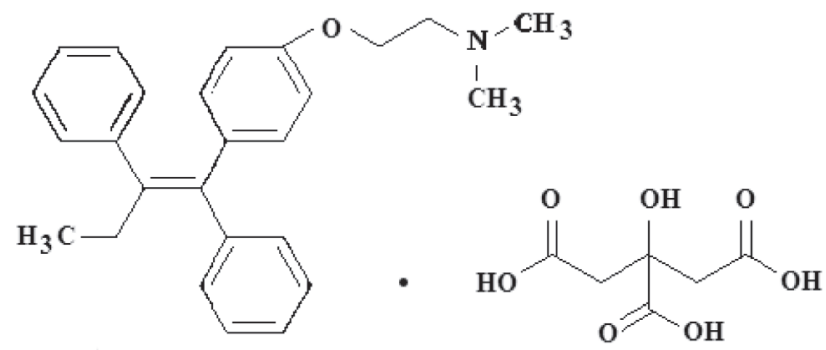

Figure 1. Structure of tamoxifen citrate

The tamoxifen citrate is available in oral tablets, being thoroughly used as endocrine therapy for breast cancer ${ }^{5,6}$. The bioavailability of the tablets of tamoxifen citrate has been extensively studied in several countries around the world ${ }^{6}$. Following a single oral dose of $20 \mathrm{mg}$ tamoxifen, an average peak plasma concentration of $40 \mathrm{ng} / \mathrm{mL}$ (range 35 to $45 \mathrm{ng} / \mathrm{mL}$ ) occurred approximately $5 \mathrm{~h}$ after dosing, the decline in plasma concentrations

*e-mail: d-santana@bol.com.br of tamoxifen is biphasic with a terminal elimination half-life of about 5 to 7 days $^{7}$. Tamoxifen is extensively metabolized after oral administration and $\mathrm{N}$-desmethyl tamoxifen is the major metabolite found in human plasma ${ }^{8}$.

The widespread use of tamoxifen has stimulated efforts to develop routine assays for this drug and its metabolites in human plasma. Procedures based on gas chromatography with mass spectrometry are highly specific and involve equipment not generally available ${ }^{9-12}$. In 1994, Fried and Wainer reported a HPLC assay that incorporates post column fluorescent activation and that avoids problems related to the variable photochemical degradation of the phenanthrenes ${ }^{13}$. The method report by Lee et al. ${ }^{14}$ represents an evolution of the Fried and Wainer ${ }^{13}$ method with three major differences: the incorporation of an internal standard in the assay, the use of a liquid-liquid extraction procedure to further purify and allow concentration of the sample, and the quantification of 4-hydroxy-N-desmethyltamoxifen, a metabolite that may have anti-cancer activity ${ }^{9,15}$. Unfortunately, the total run time achieved was about $60 \mathrm{~min}^{13}$.

The pharmaceutical preparations of tamoxifen citrate available in Brazil are based on different excipients and some coating films, which may not reflect the real bioavailability described for these tablets. Human volunteers are usually used in bioavailability tests for determination of the plasmatic concentrations of the studied medication ${ }^{6}$. In this study, healthy dogs were used as animal model in substitution to humans, due to the low cost and the satisfactory results in comparison to human volunteers ${ }^{16}$. It was also verified that the traditional methods for determination of the plasmatic concentration of the tamoxifen are generally costly, in which several sophisticated equipments are used ${ }^{14}$. Thus, a consistent and cost effective analytical methodology was adapted from literature ${ }^{17,18}$ for determination of tamoxifen in dog plasma through Highperformance Liquid Chromatographic (HPLC) coupled to ultraviolet detection, with appropriate sensitivity and selectivity to perform the bioequivalence study between two tamoxifen $(10 \mathrm{mg})$ oral formulations. 


\section{EXPERIMENTAL}

\section{Drugs and chemicals}

The organic HPLC grade solvents used for extraction and mobile phase preparation were purchased from Merck (Rio de Janeiro, RJ, Brazil). The HPLC grade solvents were used as received. All other reagents were analytical grade. Tamoxifen citrate and clomiphene citrate (internal standard) were purchased from SigmaAldrich (San Francisco, CA, USA). The deionized water was prepared using Milli-Q system (Millipore, Molsheim, France).

\section{Instruments and chromatographic conditions}

A high pressure liquid cromatography (HPLC) Hewlett Packard system was utilized in order to optimize the separation of tamoxifen and the internal standard of clomiphene. This system was composed by a controlled system, injected by hand with loop of $50 \mu \mathrm{L}$ and UV-Visible detector operated at $280 \mathrm{~nm}$. In order to optimize the method of analysis of the tamoxifen in plasma, a HPLC SPC- 10 AVvp (Shimadzu) system was employed at $280 \mathrm{~nm}$ with a controlled SCL-10Avp, auto injector SIL-10ADvp with loop of $50 \mu \mathrm{L}$, column Waters CN Nova-Pak $60 \AA$, $4 \mu \mathrm{m}$ (6 x 75 mm), a solvent delivery pump LC-10ADvp and CTO-10Avp oven.

The performance of the methodology was evaluated by using standard solutions of the compounds. After subsequent analysis of the results the methodology was optimized using plasma samples, for posterior in vivo studies. The initial mobile phase composed by a solution at $1 \%$ of ammonium acetate in methanol and acetic acid $(99: 1)^{17}$ was adjusted, as well as the flow-rate, seeking the lowest retention time of the compounds. The mobile phase applied was pumped at flow-rate of $0.3 \mathrm{~mL} / \mathrm{min}$ through the column (Waters CN Nova-Pak $60 \AA, 4 \mu \mathrm{m} 6 \times 75 \mathrm{~mm})$ at $35^{\circ} \mathrm{C}$.

\section{Standard solutions}

The standard stock solution of tamoxifen citrate was prepared by dissolving $0.0050 \mathrm{~g}$ of the standard of tamoxifen citrate in a 50 $\mathrm{mL}$ of methanol. Further dilutions were performed in order to obtain the final concentrations of $4,2,1,0.5,0.2,0.1 \mu \mathrm{g} / \mathrm{mL}$. The stock solution of the internal standard was also prepared by dissolving $0.0050 \mathrm{~g}$ of clomiphene in $50 \mathrm{~mL}$ of methanol. Similarly, dilutions were carried out to obtain a final concentration of $2 \mu \mathrm{g} / \mathrm{mL}$. Stock and working standard solutions were protected from light and stored at $-20{ }^{\circ} \mathrm{C}$ until used.

\section{Sample preparation}

To perform the determination of tamoxifen in dog plasma, blood samples were taken and placed in tubes containing EDTA. The tubes were centrifuged ( $2000 \mathrm{~g}$ for $20 \mathrm{~min}$ ) at $27^{\circ} \mathrm{C}$, in order to remove the blood elements. The plasma was then transferred to clean flasks and stored at $-70{ }^{\circ} \mathrm{C}$ for posterior analysis.

In order to provide the effective separation of tamoxifen and the internal standard (clomiphene) from plasma components, the method of extraction used was modified from the originally described by Golander ${ }^{19}$. Thus, $100 \mu \mathrm{L}$ of clomiphene $(2 \mu \mathrm{g} / \mathrm{mL})$, $3 \mathrm{~mL}$ of ammonium hydroxide $(1 \mathrm{~mol} / \mathrm{L})$ and $5 \mathrm{~mL}$ of diethyl ether were added to $2 \mathrm{~mL}$ of plasma. Then, the mixture was vortex-mixed for $2 \mathrm{~min}$. The phases were separated by centrifugation $\left(4{ }^{\circ} \mathrm{C}\right.$ for $20 \mathrm{~min}$ ) at $2000 \mathrm{~g}$. The aqueous phase was frozen in bathing of dry ice and acetone for $5 \mathrm{~min}$. The organic phase was then transferred to a new set of clean glass tubes and evaporated to dryness, under a stream of nitrogen. The residue was reconstituted with $1 \mathrm{~mL}$ of methanol.

\section{Assay validation}

To perform the assay validation of the method in dog plasma the following parameters were investigated: selectivity, linearity, precision and accuracy, ruggedness, limit of quantification, limit of detection and recovery ${ }^{20}$.

\section{Selectivity}

Selectivity is generally defined as the lack of interfering peaks at the retention times of assayed drug and the internal standard in the chromatograms. The specificity of the method was determined by comparing the chromatograms obtained from the samples containing tamoxifen and internal standard with those obtained from blank samples.

\section{Recovery and linearity}

The analytical recovery of tamoxifen was determined at concentrations of $5,10,25,50,100,200 \mathrm{ng} / \mathrm{mL}(\mathrm{n}=3)$. Drug-free plasma was spiked with known amounts of the drug to achieve the concentration previously specified. These samples were processed by the analytical method described above and peak heights were compared with the peak heights obtained by direct injection of the drugs in the mobile phase. The linearity study was carried out in the range of 5 to $200 \mathrm{ng} / \mathrm{mL}(\mathrm{n}=3)$. To access linearity, drug-free plasma was spiked with known amounts of the drug to achieve the concentrations of $5,10,25,50,100,200 \mathrm{ng} / \mathrm{mL}$ of tamoxifen and $200 \mathrm{ng} / \mathrm{mL}$ clomiphene (IS) in all the samples.

The Limit of detection (LOD) and limit of quantification (LOQ) were mathematically determined by the ratio between the standard deviation of the calibration curve and its slope, using the appropriate enhancement factor ${ }^{20-24}$.

\section{Precision and accuracy}

Precision was determined as the coefficient of variation (CV), and the accuracy as the percentage relative error (RE). Precision and accuracy data were obtained by analyzing aliquots of threespiked plasma at low $(10 \mathrm{ng} / \mathrm{mL})$ medium $(100 \mathrm{ng} / \mathrm{mL})$ and high $(200 \mathrm{ng} / \mathrm{mL})$ concentration levels of tamoxifen. Intra-day reproducibility was determined by analyzing 3 aliquots of spiked human plasma and inter-day reproducibility was determined over a 3-day period $(n=3)$.

\section{Ruggedness}

Ruggedness was determined by varying the analyst and the equipment. Precision data obtained from two different analysts, as the coefficient of variation $(\mathrm{CV})$, were obtained by analyzing aliquots of three-spiked plasma at low $(10 \mathrm{ng} / \mathrm{mL})$ medium $(100$ $\mathrm{ng} / \mathrm{mL})$ and high $(200 \mathrm{ng} / \mathrm{mL})$ concentration levels of tamoxifen. Intra-day variability was determined by analyzing 3 aliquots of spiked human plasma and inter-day variability was determined over a 3-day period $(n=3)$.

\section{Clinical protocol}

This study was performed according to an open, randomized, two-period crossover design. The test formulation of tamoxifen 
citrate by Libra-Zita ${ }^{\circledR}$ and the reference formulation of tamoxifen by Wyeth-Whitehall were used in tablets $(10 \mathrm{mg})$.

In this study, we used 14 dogs (Canium vulgaris) with race not defined (RND) divided in three groups of animals [group I $(n=5)$, group II $(n=5)$ and the control group $(n=4)]$. The group I was the reference group and the group II was the test group. The dogs were around 3.4 years old (minimum age of 2.5 years-old and maximum age of 5.5 years-old), average weight of $18.6 \mathrm{~kg}$ (minimum weight of 13 and maximum weight of $26 \mathrm{~kg}$ ). The inclusion criteria adopted were: normal clinical and laboratorial parameters, such as hematological and serologic tests, neither previous history of renal and hepatic diseases nor hypersensitivity to the tamoxifen. The exclusion criteria adopted were: any acute or chronic disease that modify the absorption, the metabolism, or excretion of the tamoxifen; animals that had taken any drug by two weeks before the beginning of the study; presence of some parasitic skin infections with no influence in the clinical and laboratorial tests. During the period of rest, it was allowed the administration of common drugs to worms (Ancylex ${ }^{\circledR}$ ou Oxprux ${ }^{\circledR}$ ), and in the cases of infections of scabies during the assay, the treatment will have to be performed with Ivomec ${ }^{\circledR}$. In order to have the possible side effects related, the dogs were daily evaluated by the researchers and the veterinarian.

The drugs were administered according to a two-period crossover design. In the first period, the animals were divided in two groups of study. During each period, the dogs were submitted to a diet with balanced standard ration to $17 \mathrm{~h} 00$ prior to the day of the study, when the fast began, seeking the begin of the study, foreseen to $6 \mathrm{~h} 00$ of the following day.

The animals of the group I received four tablets of $10 \mathrm{mg}$ of tamoxifen made by Wyeth-Whitehall ${ }^{\circledR}$ (preparation A) in single dose in the first day at $6 \mathrm{~h} 00$ in the morning. At the same time, the animals of the group II received four tablets of $10 \mathrm{mg}$ of tamoxifen made by Libra-Zita ${ }^{\circledR}$ (preparation B) also in single dose. After a rest phase of 70 days, the animals in the group I received four tablets of $10 \mathrm{mg}$ of the preparation B in single dose at $6 \mathrm{~h} 00$ in the morning. And, at the same time, the animals of the group II received in single dose four tablets of $10 \mathrm{mg}$ of the preparation A. After the ingestion of the drugs, the animals received standardized ration and were free to drink water. In order to evaluate the plasmatic levels of tamoxifen, blood samples for plasma drug assay were taken in $0.5,1.0,2.0,3.0,4.0,5.0,6.0,8.0,12,24,36,168,336$ and $504 \mathrm{~h}$. After blood clotting at room temperature, the blood samples were centrifuged at $2000 \mathrm{~g}$ for ten minutes and the plasma removed and stored at $-70{ }^{\circ} \mathrm{C}$ until assayed. Each samples were codified using an own code of numbers, that specified the number of periods, the number of study, the number of the animals and the time of sampling. The study was previously approved by the committee of ethics from the Federal University of Pernambuco.

\section{Variation of the blood cells rate in sample times}

To verify possible alteration in the haemaceas rate at the times of sampling, due to the collection of blood, the volume of cells counting percentile was accomplished in the blood samples (times of collection: 0,$5 ; 1 ; 2 ; 3 ; 4 ; 5 ; 6 ; 8 ; 12 ; 24 ; 36 \mathrm{~h}$ and in the 7 th day) in control group of dogs, without administration of any medication in the study.

\section{Data analysis}

Maximum observed plasma concentration $\left(\mathrm{C}_{\max }\right)$ and time taken to reach it $\left(\mathrm{T}_{\max }\right)$ were obtained from drug concentration vs. time curves. The areas under the tamoxifen concentrations vs. time cur- ves from 0-504 $\mathrm{h}\left(\mathrm{AUC}_{0-504 \mathrm{~h}}\right)$ were calculated using the trapezoidal method and the first order elimination rate constant $\left(\mathrm{K}_{\mathrm{e}}\right)$ was estimated using the least square regression of the points describing the terminal log-linear decaying phase. $\mathrm{T}_{1 / 2}$ were derived from $\mathrm{K}_{\mathrm{e}}$ $\left(\mathrm{T}_{1 / 2}=\ln 2 / \mathrm{K}_{\mathrm{e}}\right) \cdot \mathrm{C}_{\max }$ and $\mathrm{AUC}_{0-504 \mathrm{~h}}$ data were analyzed statistically using both parametric (one-way ANOVA) and non-parametric methods ${ }^{21,25-29}$.

\section{RESULTS AND DISCUSSION}

The tamoxifen and clomiphene solutions tested with column Waters CN Nova-Pak $60 \AA$, $4 \mu \mathrm{m}(6$ x $75 \mathrm{~mm})$ presented good retention time in all mobile phases evaluated, excepting the mobile phase composed by acetic acid: ammonium acetate $0.01 \%$ in methanol (99:1), due to the separation of the clomiphene isomers (Table 1). The mobile phases composed by methanol: acetic acid $(99: 1)+$ ammonium acetate $(0.025 ; 0.018 ; 0.014$ and $0.01 \%)$ were employed to evaluate the chromatographic behavior of tamoxifen and clomiphene in plasma (Table 2).

Table 1. Retention times of tamoxifen and its internal standard using the mobile phases composed by methanol:acetic acid (99:1) + different amounts of ammonium acetate using the standard solutions

\begin{tabular}{lccc}
\hline $\begin{array}{l}\text { Amount of } \\
\text { ammonium } \\
\text { acetate added }(\%)\end{array}$ & $\begin{array}{l}\text { Flow-rate } \\
(\mathrm{mL} / \mathrm{min})\end{array}$ & $\begin{array}{l}\text { Retention } \\
\text { time of } \\
\text { tamoxifen } \\
(\mathrm{min})\end{array}$ & $\begin{array}{l}\text { Retention } \\
\text { time of } \\
\text { clomiphene } \\
(\mathrm{min})\end{array}$ \\
\hline 1.000 & 0.5 & 3.6 & 3.3 \\
0.100 & 0.5 & 3.4 & 2.9 \\
0.050 & 0.5 & 5.5 & 4.9 \\
0.035 & 0.5 & 6.3 & 5.5 \\
0.025 & 0.5 & 7.2 & 6.1 \\
0.010 & 0.5 & 10.5 & $9.1-9.3^{*}$ \\
\hline
\end{tabular}

${ }^{*}$ Retention time of clomiphene and its isomers

Table 2. Retention times of tamoxifen and its internal standard using the mobile phases composed by methanol:acetic acid (99:1) + different amounts of ammonium acetate using the dog plasma samples

\begin{tabular}{lccc}
\hline $\begin{array}{l}\text { Amount of } \\
\text { ammonium } \\
\text { acetate added }(\%)\end{array}$ & $\begin{array}{l}\text { Flow-rate } \\
(\mathrm{mL} / \mathrm{min})\end{array}$ & $\begin{array}{l}\text { Retention } \\
\text { time of } \\
\text { tamoxifen } \\
(\mathrm{min})\end{array}$ & $\begin{array}{l}\text { Retention } \\
\text { time of } \\
\text { clomiphene } \\
(\mathrm{min})\end{array}$ \\
\hline 0.025 & 0.5 & 4.2 & 5.0 \\
0.018 & 0.5 & 10.0 & 8.5 \\
0.014 & 0.5 & 12.3 & 10.3 \\
0.01 & 0.3 & 15.2 & $12.4-12.6^{*}$ \\
\hline
\end{tabular}

* Retention time of the peaks of clomiphene and isomers

Within the tested mobile phases, the composition of $0.014 \%$ of ammonium acetate in methanol and acetic acid (99:1) presented the best retention time, as well as a good separation from the plasmatic proteins. The retention times of the tamoxifen and its internal standard were 12.3 and $10.3 \mathrm{~min}$, respectively. The typical chromatograms of tamoxifen and its internal standard in dog plasma, with the selected mobile phase are displayed in the Figure 2.

The accuracy and the precision met the expected rate. The coefficient of variation did not exceed at $15 \%$ in the analyses, and 


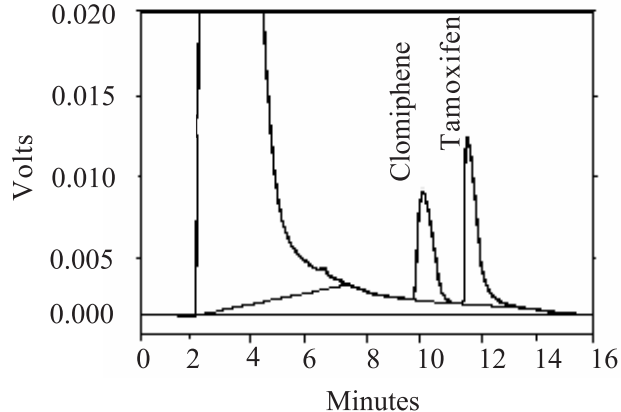

Figure 2. Chromatogram of tamoxifen citrate and its internal standard (clomiphene) in plasma. Eluente with mobile phase 0,014\% of acetate of ammonium in methanol:acetic acid (99:1)

were considered acceptable according to Agência Nacional de Vigilância Sanitária (ANVISA) ${ }^{20}$. ANVISA is the regulatory agency responsible for health surveillance in Brazil (Table 3). The proposed method was found to be rugged when analyst was varied (Table 4). A good recovery at the concentrations of 5, 10, 25, 50, 100, $200 \mathrm{ng} /$ $\mathrm{mL}$ was obtained, with values ranging from 97.35 to $103.64 \%$. The limit of detection and quantification were 0.981 and $2.97 \mathrm{ng} / \mathrm{mL}$, respectively, these results are in agreement with the study performed by Gjerde $^{9}$ that found the limit of quantification of $1.0 \mathrm{ng} / \mathrm{mL}$ to tamoxifen.

Table 3. Determination of the precision and accuracy of tamoxifen in dog plasma $(n=3)$

\begin{tabular}{llcll}
\hline $\begin{array}{l}\text { Concentration } \\
\text { added }(\mathrm{ng} / \mathrm{mL})\end{array}$ & $\begin{array}{l}\text { Concentration } \\
\text { obtained }(\mathrm{ng} / \mathrm{mL})\end{array}$ & $\begin{array}{l}\mathrm{CV} \\
(\%)\end{array}$ & $\begin{array}{l}\mathrm{RE} \\
(\%)\end{array}$ \\
\hline Intra-day & 10 & 10.003 & 8.78 & 100.03 \\
& 100 & 93.110 & 9.56 & 93.11 \\
& 200 & 200.500 & 10.16 & 100.25 \\
\hline Inter-day & 10 & 10.282 & 14.05 & 102.86 \\
& 100 & 101.110 & 13.72 & 101.11 \\
& 200 & 206.180 & 13.16 & 103.09 \\
\hline
\end{tabular}

It was verified that the linear model describes appropriately the relationship between the peak-heights ratio and the concentration at the range from $5-200 \mathrm{ng} / \mathrm{mL}$. Figure 3 shows the calibration curve obtained by chromatographic analysis of tamoxifen in dog plasma. The ratio of $3.259\left(\mathrm{MQ}_{\mathrm{faj}} / \mathrm{MQ}_{\mathrm{pe}}\right)$ is $0.75 \mathrm{~F}$ inferior to the value of $F$ with 3 and 2 degrees of freedom. The coefficient of 4.494, $\mathrm{F}\left(\mathrm{MQ}_{\mathrm{reg}} / \mathrm{MQ}_{\mathrm{r}}\right)$ is 1025.46 superior to the value $\mathrm{F}$ with 2 and 3 degrees of freedom (Table 5). The variance $\left(S^{2}\right)$ in ' $y$ ', was constant
Table 4. Determination of the ruggedness of tamoxifen in dog plasma

\begin{tabular}{|c|c|c|c|c|}
\hline & ation & \multicolumn{2}{|c|}{$\begin{array}{l}\text { Precision } \\
\mathrm{CV}(\%)\end{array}$} & \\
\hline & \multirow{2}{*}{\multicolumn{2}{|c|}{$\begin{array}{c}\text { Intra-day } \\
\text { Day } 1\end{array}$}} & \multicolumn{2}{|c|}{ Inter-day } \\
\hline & & & \multirow{2}{*}{$\begin{array}{c}\text { Day } 2 \\
\text { Analyst } 1\end{array}$} & \multirow{2}{*}{$\begin{array}{c}\text { Day } 3 \\
\text { Analyst } 2\end{array}$} \\
\hline & Analyst 1 & Analyst 2 & & \\
\hline 10 & 13.51 & 12.13 & 15.44 & 15.06 \\
\hline 100 & 4.82 & 11.21 & 14.16 & 15.26 \\
\hline 200 & 9.39 & 11.72 & 7.81 & 14.47 \\
\hline
\end{tabular}

along all calibration range, meaning that the data are homoscedastic and could discard the existence of heterocedasticity ${ }^{30-32}$.

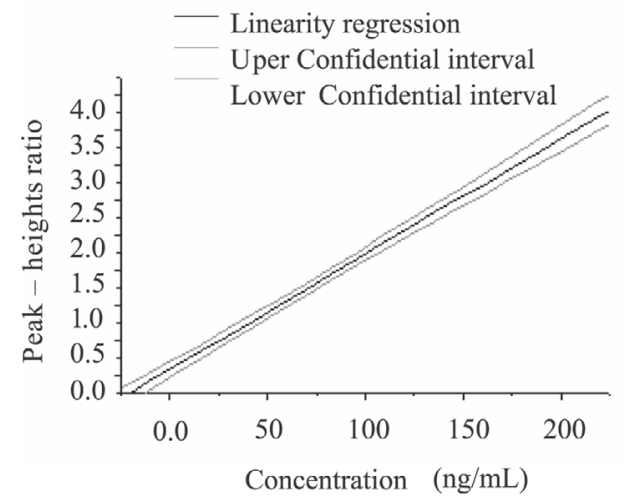

Figure 3. Calibration curve obtained through the chromatographic analysis of tamoxifen in dog plasma

There was no significant variation in the haemaceas rate during the blood collections. The dogs of the control group (14, 21, 22 and 23) presented haemaceas percentile averages respectively equal to 37.73 $(\mathrm{CV} \%=9.22) ; 36.65(\mathrm{CV} \%=12.00) ; 48.76(\mathrm{CV} \%=5.29)$ and 42.42 $(\mathrm{CV} \%=8.42)$. The geometric mean ratios for $\mathrm{AUC}_{0-504 \mathrm{~h}} \mathrm{AUC}_{0 .,}, \mathrm{C}_{\max }$, $\mathrm{T}_{\max }, \mathrm{T}_{1 / 2}$ and $\mathrm{K}_{\mathrm{e}}$ of the two tamoxifen oral formulations are shown in Table 6 . The tablets of tamoxifen citrate were absorbed quickly after oral ingestion, taking approximately 1:00h for the "Drug A" tablets, and 2:00h for the "Drug B" tablets. Adverse effects were not observed during the study. The calibration curves of tamoxifen presented good linearity ( $r>0.95$ ), according to the parameters established by Food

Table 5. Analysis of variance of the tamoxifen calibration curve in plasma

\begin{tabular}{lccc}
\hline Source & \multicolumn{2}{c}{ Variance Analysis } & \\
\hline Regression & Square Sum & Square Average & Freedom Degree \\
Residual & $2.462476 \mathrm{e}+001$ & $2.462476 \mathrm{e}+001$ & 1 \\
Adjustment fault & $3.842143 \mathrm{e}-001$ & $2.401340 \mathrm{e}-002$ & 16 \\
Absolute Error & $7.681770 \mathrm{e}-002$ & $1.920442 \mathrm{e}-002$ & 4 \\
Total & $3.073966 \mathrm{e}-001$ & $2.561639 \mathrm{e}-002$ & 12 \\
\hline \multicolumn{2}{c}{$\mathrm{F}\left(\mathrm{MQ}_{\mathrm{reg}} / \mathrm{MQ}_{\mathrm{r}}\right)=1025.46$} & $1.471116 \mathrm{e}+000$ & 17 \\
\multicolumn{2}{c}{$\mathrm{F}\left(\mathrm{MQ}_{\mathrm{faj}} / \mathrm{MQ}_{\mathrm{pe}}\right)=0.75$} & & $\mathrm{~F}_{\text {tabelado }}=4.494$ \\
\hline
\end{tabular}

Detailed Variance $=98.46 \%$; Maximum Detailed Variance $=98.77 \%$ 
Table 6. Mean pharmacokinetic parameters obtained from 10 healthy dogs after the administration of both 10 mg tamoxifen formulations

\begin{tabular}{|c|c|c|c|}
\hline Parameters & $\begin{array}{l}\text { Drug A } \\
(\text { Standard }-\mathrm{n}=5)\end{array}$ & $\begin{array}{l}\text { Drug B } \\
(\text { Test }-\mathrm{n}=5)\end{array}$ & $\begin{array}{l}\text { Drug B/ Drug A } \\
\text { Ratio }(\%)\end{array}$ \\
\hline $\mathrm{AUC}_{0-504}\left(\mu \mathrm{g} \mathrm{h} / \mathrm{mL}^{-1}\right)$ & 0.3541 & 0.3050 & 0.861 \\
\hline Geometric Mean CV (\%) & 23.92 & 73.38 & \\
\hline 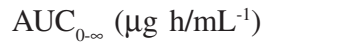 & 0.5397 & 0.3950 & 0.732 \\
\hline Geometric Mean CV (\%) & 46.66 & 44.25 & \\
\hline $\mathrm{C}_{\max }\left(\mu \mathrm{g} \mathrm{h} / \mathrm{mL}^{-1}\right)$ & 0.5376 & 0.5341 & 0.9934 \\
\hline Geometric Mean CV (\%) & 50.38 & 31.02 & \\
\hline $\mathrm{T}_{\max }(\mathrm{h})$ & 5.23 & 3.99 & 0.762 \\
\hline Geometric Mean CV (\%) & 56.39 & 26.56 & \\
\hline $\mathrm{T}_{1 / 2}(\mathrm{~h})$ & 6.53 & 3.62 & 1.306 \\
\hline Geometric Mean CV (\%) & 247.90 & 146.16 & \\
\hline $\operatorname{Ke}\left(h^{-1}\right)$ & 0.0960 & 0.1257 & 0.554 \\
\hline Geometric Mean CV (\%) & 142.29 & 85.35 & \\
\hline
\end{tabular}

Table 7. Statistic analysis of values at $90 \%$ of confidence interval

\begin{tabular}{lcccc}
\hline \multicolumn{4}{c}{ Bioavailability Ratio (Drug B vs Drug A) (\%) } \\
\hline Procedures & $\mathrm{AUC}_{0-504}$ & $\mathrm{AUC}_{0-\infty}$ & $\mathrm{C}_{\max }$ & $\mathrm{T}_{\max }$ \\
Westlake's & $67.10-132.89$ & $51.42-148.57$ & $54.98-145.00$ & $13.48-186.56$ \\
\hline Linear data & $59.80-123.50$ & $49.80-149.70$ & $50.70-88.80$ & $87.00-257.20$ \\
Transformed data & $60.40-125.92$ & $53.83-153.09$ & $51.67-84.19$ & $14.61-185.38$ \\
Period 2 x Period 1 & $62.70-129.00$ & $38.20-120.80$ & $53.70-93.40$ & $46.90-133.20$ \\
Two one-sided t test & 0.2791 & 0.1877 & 0.9095 & 0.6618 \\
Steinjans & $56.20-193.80$ & $72.40-149.30$ & $52.40-80.70$ & $100.0-219.10$ \\
\hline
\end{tabular}

and Drug Administration (FDA) ${ }^{25}$. The "Drug A (Tamoxifen ${ }^{\circledR}$ - WyethWhitehall)" reached $\mathrm{C}_{\max }$ in approximately $3 \mathrm{~h}(53.76 \mathrm{ng} / \mathrm{mL})$ and "Drug B (tamoxifen citrate, Libra - Zita $\left.{ }^{\circledR}\right)$ " after $4 \mathrm{~h}(53.41 \mathrm{ng} / \mathrm{mL})$ of the administration (Figure 4). At the beginning of the study (among 1$4 \mathrm{~h}$ ) no good correlation between "Drug B" and "Drug A" was observed, since "Drug A" reached the plasmatic concentration of $40.59 \mathrm{ng} / \mathrm{mL}$ in 2:00 h while "Drug B" presented only $16.75 \mathrm{ng} / \mathrm{mL}$, being totally eliminated after $12 \mathrm{~h}$ in both formulations. The bioavailability of the test was calculated by the percentile ratio "Drug B: Drug A" for the geometric mean values of $\mathrm{AUC}_{0-504}, \mathrm{AUC}_{0 .}, \mathrm{C}_{\max }, \mathrm{T}_{\max }$ and the values are respectively $86.18,73.28,99.34$ and 76.29 . The pharmacokinetic parameters $\mathrm{AUC}_{0-504}$ and $\mathrm{T}_{\max }$ are out of the range (80-125\%), established by FDA ${ }^{25}$ and ANVISA" ${ }^{20}$. The ratio of bioavailability "Drug B vs Drug A" are presented in the Table 7 for the different procedures performed, with and without logarithmic transformation. For $\mathrm{AUC}_{0}$ ${ }_{504}, \mathrm{AUC}_{0 .}, \mathrm{T}_{\max }$ and $\mathrm{C}_{\max }$ the confidence interval for all the parameters was of $50-160 \%$, considered out of the bioequivalence limits by the ANVISA $^{20}$. The method presented here is less sensitive than other available assays, i.e., $2.97 \mathrm{ng} / \mathrm{mL}$. However, this level of sensitivity

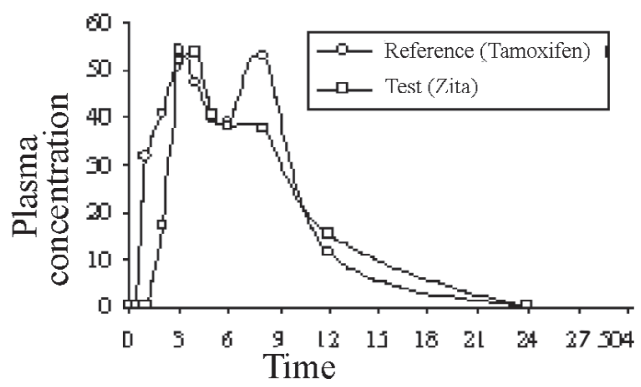

Figure 4. Medium profile of tamoxifen plasmatic concentration of "drug A and drug B" was sufficient to perform the bioequivalence study. Considering the fact that the present method involves a shorter running time and a simple equipment configuration and sample preparation process, it may be used in similar studies as a time and cost effective alternative to other available methods.

\section{CONCLUSIONS}

The validated HPLC method employed here proved to be simple, fast, reliable, selective and sensitive enough to be used in clinical pharmacokinetic studies of tamoxifen in dog plasma. The present study shows that "DRUG A" was not bioequivalent to "DRUG B", in terms of both rate and extent of absorption, as assessed by the appearance of $90 \% \mathrm{CI}$ for $\mathrm{AUC}_{0-504}, \mathrm{AUC}_{0 . .}, \mathrm{C}_{\max }$ and $\mathrm{T}_{\max }$ ratios out of the $80-125 \%$ interval proposed by the FDA ${ }^{25}$ and ANVISA ${ }^{20}$. These differences can be associated to the gastrointestinal physiologic differences from dogs to humans, such as lower absorption of tamoxifen due to the faster gastrointestinal traffic or to the faster metabolism and elimination of the tamoxifen ${ }^{33}$. This study suggests, as sequence, the assay validation using human plasma, as well as, the accomplishment of the bioavailability study of tamoxifen in human beings.

\section{ACKNOWLEDGEMENTS}

The authors are grateful to Dr. J. A. da Silva, by the attention and supervision in the accomplishment of the in vivo assay, and to all employees from Federal University of Pernambuco Experimental Surgery Division, especially to Silvano, Damião, Elidece and Domingos, by the technical support in the in vivo assay. The authors also wish to thank M. Santos and L. Carvalho from Barão de Lucena Hospital, for the support given at the beginning of this study and to $\mathrm{CNPq}$ for the financial aid. 


\section{REFERENCES}

1. Chemical Abstracts Registry Data, American Chemical Society, Cassi CDRom, 2007.

2. Novaldex Professional Information Brochure. Astra-Zeneca, 2002, p. 16.

3. Physicians' Desk Reference, $47^{\text {th }}$ ed., 1993, p. 1126.

4. Gleiter, C. H.; Klotz, U. J. Clin. Pharmacol. 1998, 38, 904.

5. Legha, S. S.; Carter, S. K.; Ann. Intern. Med., 1976, 84, 751.

6. Braga, R. M. C.; Dissertação de Mestrado, Universidade Federal de Pernambuco, Brasil, 2000.

7. Furr, B. J. A.; Jordan, V. C.; Pharmacol. Ther. 1984, 25, 127.

8. Fuchs, W. S.; Leary, W. P.; Arzeneim. Forsch. 1996, 46, 255.

9. Gjerde, J.; Kisanga, E. R.; Hauglid, M.; Hola, P. I.; Mellgren, G.; Lien, E. A.; J. Chromatogr., A 2005, 1082, 6.

10. Mihailescu, R.; Aboul-Enein, H. Y.; Efstatide, M. D.; Biomed. Chromatogr. 2000, 14, 180 .

11. Merle, O.; Faure, N.; Guitton, J.; Burke, M. D.; Ollagnier, M.; Anal. Lett. $1998,31,2679$

12. Merle, O.; Guitton, J.; Burke, M. D.; Ollagnier, M.; Anal. Lett. 1998, 31, 2067.

13. Fried, K. M.; Wainer, I. W.; J. Chromatogr., B: Anal. Technol. Biomed. Life Sci. 1994, 655, 261

14. Lee, K.; Ward, B. A.; J. Chromatogr., B: Anal. Technol. Biomed. Life Sci. 2003, 791, 245.

15. Kisanga, E. R.; Haugan Moi, L. L.; Gjerde, J.; Mellgren, G.; Lien, E. A.; J. Steroid Biochem. Mol. Biol. 2005, 94, 489.

16. Lima, E. Q.; Dissertação Mestrado, Universidade Federal de Pernambuco, Brasil, 2000.

17. Sane, R. T.; Sonawane, K. K.; Kubal, M. L.; Nayak, V. G.; Indian Drugs 1986, 24, 154
18. Lim, K. C.; Chow, L. C. L.; Yuan, Z.; Smith, L. L.; Biomed. Chromatog. $1993,7,311$.

19. Golander, Y.; Sternson, L. A.; J. Chromatogr. 1980, 181, 41.

20. Agência Nacional de Vigilância Sanitária (ANVISA); Resolução RE $n^{\circ} 899$, de $29 / 05 / 2003$.

21. International Conference on Harmonisation (ICH); Validation of Analytical Procedures: Text and Methodology, Q2 (R1), 2005.

22. Fonseca, S. G.; Silva, L. B. L.; Castro, R. F.; Santana, D. P.; Quim. Nova 2004, 27, 157 .

23. Ribani, M.; Bottoli, C. B. G.; Collins, C. H.; Jardim, I. C. S. F.; Melo, L. F. C.; Quim. Nova 2004, 27, 771.

24. Abreu, L. R. P.; Ortiz, R. A. M.; J. Pharm. Sci. 2003, 6, 223

25. United States Food and Drug Administration (US-FDA); Guidance for Industry, Bioanalytical Method Validation, 2001.

26. Green, J. M.; Anal. Chem. 1996, 68, A305.

27. Miller, J. C.; Miller, J. N.; Statistics for Analytical Chemistry, $2^{\text {nd }}$ ed., Ellis Horwood: Chichester, 1988.

28. Swartz, M. E.; Krull, I. S.; Analytical Method Development and Validation, Marcel Dekker, Inc.: New York, 1997.

29. Barros Neto, B.; Scarminio, I. S.; Bruns, R. E.; Como Fazer Experimentos, Ed. da Unicamp: Campinas-SP, 2001.

30. Crow, E. L.; Davis, F. A.; Maxfield, M. W.; Statistical Manual, Dover Publication: New York, 1960.

31. Massart, D. L.; Vanderginste, B. G. M.; Deming, S. N.; Chemometrics: textboo, Elsevier Science B. V.: Amsterdam, 1988.

32. Farrant, T. J.; Pratical statistics for the analytical scientist. Laboratory Laboratory of the Government Chemist by the Royal Society of Chemistry: Cambrigde, 1997.

33. Waddle, J. R.; Fine, R. L.; Case, B. C.; Trogdon, M. L.; Tyczkowsk, K.; Frazier, D.; Page, R. L.; Cancer Chemoth. Pharm. 1999, 44, 74. 